\title{
Improving Students' Writing Skill in Descriptive Text Using Video Through Think Pair Share MetShod
}

\author{
Ageng Jauhar Bani Waluyo, Dewi Rochsantiningsih, Abdul Asib \\ English Education Department \\ Teacher Training and Education Faculty \\ Sebelas Maret University of Surakarta
}

Email: agengjauhar@gmail.com

\begin{abstract}
The objectives of the research are: (1) to identify whether or not and to what extent video through Think Pair Share (TPS) method enhances Students' writing skill; and (2) to describe the class climate when video through TPS method is implemented in the writing class. The research was carried out at a Junior High School in Blora, Central Java in the academic year of 2014/2015. The research was conducted in two cycles, each cycle consisted of four meetings. It applied the use of video as the medium and TPS as the method for teaching writing. The qualitative data were collected through observation, diary, interview, and questionnaires. The quantitative data were collected using test. Those qualitative data were analyzed by qualitative methods; assembling the data, coding the data, comparing the data, building interpretations, reporting the outcomes. Meanwhile, the quantitative data were analyzed by calculating the mean score of pre test, test 1 and post test. The research findings show that the use of video through TPS method can enhance the students' writing skill and lead the class climate of writing class better than the situation prior to the research implementation: (1) stating the main idea of their writings; (2) applying the appropriate words to express their ideas; (3) ordering words into sentences correctly; (4) writing the words in correct spelling; and (5) Making a text in correct generic structure. The class climate also improves, the students: (1) are active and pay attention to the teacher's explanation; (2) do not mind their personal businesses anymore; (3) do not do useless noise during the class activity (4) are interested in the lesson, they take part in all activities and keep focus in the lesson. In addition, the students' mean score also improved which can be seen from their writing mean score of pre test, test in cycle 1 , and cycle 2 , that is $50.40,70.11$, and 78.38, the last mean score is higher than KKM which is 70.00 .
\end{abstract}

Keywords: writing, descriptive text, video, Think Pair Share method, action research

\section{INTRODUCTION}

In general, the goal of teaching English at school is students are able to communicate in English. Mastering English means mastering language skills such as speaking, listening, reading, and writing. Writing important skill that should be masterd by the students in school because the students are expected to have capability in expressing their idea through writing. Byrne (1997: 1) writing is producing a sequence of sentences arranged in a particular order and linked together in certain ways. A sequence of sentences whether it is short or long after being put in order and linked together, they will form a 
coherent whole. This coherent whole is called a text. A text may consist of one paragraph or more expressing an idea.

Jeffery and Archibald in Abdelsamea (2014: 49) defined writing skill as a compound activity and a multifaceted skill requiring proficiency in many other skills. According to Widdowson (1996: 62) writing is described as the use of medium to manifest the graphology and grammatical system of the language. It means, in a sense, writing is the production of sentences. The sentences are used to create a discourse and each sentence takes on a particular value as a part of the discourse.

Descriptive is one of text types that must be learnt by Junior High School, especially the 8th grade students. Emilia (2011: 82) states that descriptive text is a text which is used to describe a particular person, place or thing or something in writer's mind. The purposes of this text is to describe person, place or thing. The process of writing descriptive text shows how well that the students arrange and do creative process dealing with the foreign language that they are learnt especially in writing process.

According to them, English was difficult and writing was, too. They had low writing skill. Their low writing skill was indicated by some indicators: (1) Students often made mistakes in stating main idea for their writings. They had difficulties in exploring idea to write. They did not know what to write; (2) Students' word choices were limited. Students sometimes found difficulties in applying the appropriate words to express their ideas; (3) Students made many mistakes in word order. They often made many mistakes when ordering words into sentences; and (4) Students writing lack of cohesiveness and coherence. Students did not get specific guidance of how to write systematically; and

Students made mistakes in grammar.

I would like to solve the problems by using an interesting teaching media to stimulate students' interest in learning process. One of the interesting teaching strategies is to use a media in conducting teaching and learning process. Celce (2001:

460) defines media as "any technological innovations in Language teaching and is designed for classroom teaching purposes". It can be concluded that teaching media is any aids which carries information between a source and a receiver and is aimed to facilitate communication and learning. Teaching media is a concrete thing that can be used by the teacher to convey material, for example picture, video, tape recorder, computer, internet, etc.

Information and communication technologies (ICTs) have many advantages as a teaching media in learning process. ICT can be used as interesting media in teaching writing since ICT can be useful as a means of communication to convey the message. It also enables teacher to increase students' motivation in learning English through various enjoyable and attractive activities.

In this research, I used video as the media. According to Copper (1991: 11), video is a supercharged medium of communication and powerful vehicle of information that is packed with message, images, and ambiguity, and so represents a rich terrain to be worked and reworked in the language learning classroom. Smaldinho (2002: 283) defines video as electronic storage of moving images. He adds that any electronic media format that employs "moving picture" to present a message can be referred as video.

Video is an interesting media because it is an audio-visual medium that is not only providing sound but also picture that can move. Video communicates 
meaning better than other media. Video presents language in context in ways that a casette can't. Learners can see who's or what's speaking, where the speakers are, what they're doing, etc. All these visual clues can help comprehension. Video can be made by capturing using camera and editing the movie or television broadcasting using computer. It's such an interesting thing for students to study because there will be many new innovations in writing activities that will improve their writing skill especially in writing descriptive text. It also improves student's focus in writing because their attention will shift to the video that shows about the story that they are going to write. In the video, the story is organized in a good plot so the students can enjoy the story. It helped them to write about what had been seen in the video.

Beside use teaching media, a teacher must also use an interesting method to enhance the students' writing skill. I intend to overcome the problems to enhance the students' writing ability by using Think Pair Share (TPS) Method. I believe that Think Pair Share is a good method in conducting writing activity. By conducting a classroom action research that implements Think Pair Share Method, it is expected that the teacher is able to improve the students' writing skill. Sumarsih \& Sanjaya (2013: 109) states that Think-Pair-Share is a strategy designed to provide students with "food for thought" on a given topics enabling them to formulate individual ideas and share these ideas with another student. It is a learning strategy developed to encourage student classroom participation. Rather than using a basic recitation technique in which a teacher poses a question and one student offers a response, Think-Pair-Share encourages a high degree of pupil response and can help keep students on task.
With Think Pair Share, students were gave time to think through their own answers to the question(s) before the questions were answered by other peers and the discussion moves on. Students also had the opportunity to think with another student about their responses before being asked to share their ideas publicly. This strategy provides an opportunity for all students to share their thinking with at least one other student. It increases their sense of involvement in classroom learning. Think Pair Share is simple but it's very useful to students. Coffey states in the Think Pair Share method, students think on their own about topic and then pair with another student to discuss their thoughts. Finally, the pair shares their thoughts with the rest of the class. The structure facilitates independent thinking and fosters a sense of confidence while engaging students in revising their hyphotesis based on others' opinion.

Considering the advantages of video and Think Pair Share Method as mentioned above, the researcher has a strong belief that using video through TPS Method in a classroom can enhance students' writing skill. Hopefully the improvement of their writing skill will be helpful for the students' communicative competence.

\section{RESEARCH METHODS}

The method used in this study is classroom action research. There are some definitions of action research proposed by experts. Wallace (1998: 4) defines action research as a way of reflecting on teacher's teaching that is done systematically by collecting data on their everyday practice and analyzing it in order to come to some decisions about what their future practice should be.

According to Mills (2000:5) proposes action research as systematic inquiry done by the teachers or other 
individuals in teaching or learning environment to gather information about and subsequently improve the ways their particular school operates, how they teach, and how well the students learn. Burns (1994: 293) says that action research is the application of fact finding to solve practical problem in a social situation with a view to improve the quality of action within it, involving the collaboration and cooperation of researchers, practitioners and laymen.

The research is conducted in two cycles, each cycle consisted of four meetings. The qualitative data are collected through observation, diary, interview, and questionnaires. The quantitative data are collected using test. Those qualitative data were analyzed by qualitative methods; assembling the data, coding the data, comparing the data, building interpretations, reporting the outcomes. Meanwhile, the quantitative datas were analyzed by calculating the mean score of pre test, test 1 and post test.

\section{RESEARCH FINDINGS AND DISCUSSIONS}

The use of video through TPS method had improved the students' writing skill. It can be seen from their improvement in mean score and each indicator; content, organization, word choice, grammar, and mechanics. The result are presented in table 1.1 and 1. 2.

Table 1.1. The result of pre test, test 1 and post test

\begin{tabular}{clccc}
\hline No & Explanation & Pre-test & test 1 & Post-test \\
\hline 1 & Highest Score & 70.75 & 82.00 & 87.00 \\
2 & Lowest Score & 40.50 & 61.00 & 73.00 \\
3 & Mean Score & 50.40 & 70.11 & 78.38 \\
\hline
\end{tabular}

Table 1.2. The result of each indicator in pre test, test 1, and post test

\begin{tabular}{clccc}
\hline No & Aspect & Pre-test & test 1 & Post-test \\
\hline 1 & Content & 13.73 & 20.46 & 22.32 \\
2 & Organization & 11.20 & 14.25 & 15.40 \\
3 & Word Choice & 11.35 & 14.51 & 15.20 \\
4 & Grammar & 12.35 & 17.73 & 21.22 \\
5 & Mechanics & 1.76 & 3.14 & 4.21 \\
& Total & 53.82 & 70.11 & 78.38 \\
\hline
\end{tabular}

The results prove that video through Think Pair Share method improve writing skill. This result is suppported by Stamplesky (1990: 6-7), explains that most video sequence can serve more than one purpose, depending on teacher's objective for lesson such as: active viewing, vocabulary, grammar, pronounciation, listening/speaking skill, reading/writing skill, cross-cultural concerns and testing. According to Merchelina (2012: 17-19) the benefits of TPS method are TPS to improve gaining ideas to write, TPS to improve vocabulary, TPS to improve grammar, TPS to improve conjunction use.

Beside observing the score, the researcher observed the class situation, too. The students' improvement was not only found in each indicator but also in class situation. The improvement are presented in the table 1.3 . 
Table 1. 3. Table of the Students' Improvement in class situation

\begin{tabular}{|c|c|c|c|}
\hline No & Research Findings & Before Action Research & After Action Research \\
\hline 1 & The class situation & $\begin{array}{l}\text { a. The students were passive } \\
\text { learners } \\
\text { b. The students were noisy } \\
\text { during the class activity } \\
\text { c. The students paid little } \\
\text { attention toward the } \\
\text { teacher }\end{array}$ & $\begin{array}{l}\text { a. The students were active } \\
\text { learners } \\
\text { b. The students were not doing } \\
\text { useless noisy during the } \\
\text { class activity } \\
\text { c. The students paid full } \\
\text { attention toward the teacher }\end{array}$ \\
\hline 2 & $\begin{array}{l}\text { The improvement } \\
\text { of the students } \\
\text { learning activity }\end{array}$ & $\begin{array}{l}\text { a. The students got bored in } \\
\text { the teaching learning } \\
\text { process, especially in } \\
\text { writing skill } \\
\text { b. Only certain students who } \\
\text { were active } \\
\text { c. The students got difficulty } \\
\text { in making a text }\end{array}$ & $\begin{array}{l}\text { a. The students enjoyed and } \\
\text { interested in the classroom } \\
\text { situation } \\
\text { b. All the students involved in } \\
\text { activity of teaching learning } \\
\text { process } \\
\text { c. The students solved the } \\
\text { problems by learning the } \\
\text { paper }\end{array}$ \\
\hline
\end{tabular}

From the table 1. 3, it can be seen that there are positive improvement in class situation after the implementation of video through Think Pair Share Method. Before the action, it was found that the students were passive, noisy during the class activity, paid little attention toward the teacher. After the action, the students were active, not doing useless noisy during the class activity, paid full attention toward the teacher. The results prove that video through Think Pair Share method able to refine the class situation. It is supported by Stamplesky (1990: 76) states that the importance of video as a language teaching aid. First of all, video can increase student's motivation. Children and adult feel their interest quicken when language is experienced in a lively way through television and video. Video can present language more comprehensively than any other teaching medium. Second, video can be used as a means of communication. A video sequence that is used in class makes the students more ready to communicate in the target language. Third, non-verbal aspect of communication can be presented by video. Video allows the viewer to see the non-verbal communication, such as gesture, expression, posture, etc. Finally, by using video, cross culture comparison can be done in the language teaching. Video is a rich resource for communication in the language classroom including the cultural behavior.

\section{CONCLUSIONS AND SUGGESTIONS}

Based on the research results presented above, it can be concluded that video through TPS Method improve the students' writing skill. The improvement can be clearly shown in the students' scores. The result of pre test showed that the mean score of the students was 50.40. The score was under the passing grade that was 70.00. After the video through TPS Method was implemented, the students' mean score increased to 70.11 after cycle 1 and it finally rose to 78.38 after cycle 2 .

Besides, video through TPS method refine the class condition. Before the research, the students were passive, noisy during the class activity, paid little attention toward the teacher. After the research, the students were active, not doing useless noisy during class activity, paid full attention toward the teacher.

Having concluded the result of the research, I would like to propose some suggestions for the students. They should active in the activities during the lesson. 
They also need to give their full attention when the teaching and learning process runs. Regarding to writing skill, the students need to do more exercises in writing. For the teacher, the researcher suggests that an English teacher should know how to enhance students' ability in teaching and to develop a good classroom situation, so that the students learn easily and comfortably in their class. Finally, for other researchers who want to use Think Pair Share Method in their research, the research wants to suggest that they should read more references to get more complete information about Think Pair Share.

\section{BIBLIOGRAPHY}

Abdelsamea, M. A., Eldardeer, A. A., Eldowy, M. A. \& Verma, S. 2014. Exploring the Relationships among Metalearning, Cognitive Holding Power and English Writing Skills of Pre-service Teachers in Egypt. International Journal of English Language \& Translation Studies. 2(2), 46-58: Retrieved from http://www.eltsjournal.org

Burns, Anne. 1999. Collaborative Action Research for English Language Teachers. New York: Cambridge University Press

Byrne, Donn. 1997. Teaching Writing Skill. London: Harlow, Essex: Longman

Celce, Mercia M. 2000. Discorse and Context in language teaching. A guide for language teacher. Cambridge: Cambridge University Press

Copper, Richard. 1991. Video. Oxford: Oxford University Press

Emilia, E. 2011. Pendekatan Genre-Based dalam Pengajaran Bahasa Inggris:
Petunjuk untuk Guru. Bandung: Rizky Press

Lucy A, Merchelina. 2012. Improving Students' Writing Skill by Using Think Pair Share (TPS) (A Classroom Action Research at the Eight Grade Students of Smp Negeri

1 Jaten in the Academic Year of 2011/2012). Unpublished Undergraduate Thesis. Sebelas Maret University: Surakarta

Mills, Geoffrey E. 2000. Action Research: A Guide for the Teacher Researcher. New Jersey: Prentice Hall Inc

Smaldinho, Sharon, E. 2002. Instructional Technology and Media for Learning. New Jersey: Upper Saddle River Columbus Ohio

Stamplesky, S and B. Tomalin. 1990. Video in Action. New York: Prentice Hall

Sumarsih \& Sanjaya, D. 2013. TPS as an Effective Technique to Enhance the Students' Achievement on Writing Descriptive Text. Retrieved from www.ccsenet.org/elt

Widdowson, H. G. 1996. Teaching Language as Communication. New York: Oxford University 